\title{
High Rate of Hepatitis C Virus Infection in an I solated Community: Persistent Hyperendemicity or Period-Related Phenomena?
}

\author{
Mei-Shang Ho, ${ }^{1,2 *}$ Chien-Pang Hsu, ${ }^{1,2}$ Yau Yuh, $^{3}$ Chwan-Chuen King, ${ }^{2} \mathrm{~J}$ ung-Fa Tsai, ${ }^{4}$ Yi-Chien Mau, $^{1}$ \\ Li-Ching Hsu, ${ }^{3}$ and Wan-Hwa Chao, ${ }^{1,3}$ \\ ${ }^{1}$ Division of Epidemi ol ogy \& Public Health, Institute of Biomedical Sciences, Academia Sinica, Taipei, Taiwan \\ IInstitute of Epidemiology, College of Public Health, National Taiwan University, Taipei, Taiwan \\ ${ }^{3}$ Field Epidemiol ogic Training Program and National Institute of Preventive Medicine, Department of Health, \\ Taipe, Taiwan \\ ${ }^{4}$ Department of Internal Medicine, Kaohsiung Medical College, Kaohsiung, Tai wan
}

We investigated underlying risks for hyperendemic hepatitis C virus (HCV) infection among the 1853 inhabitants of a mountainous village in Eastern Taiwan with high prevalence of HCV and hepatitis B virus (HBV). Among the 80 selected adults, we found that having resided away from the village before 1985 was protective against HCV infection, while residing in the village after 1985 posed little risk for HCV infection to children and young adults $<30$ years of age. Among the 559 school children 7 through 14 years of age, anti-HCV prevalence was $1.9 \%$, and the HBV carrier rate was 29\%. Following up 270 children 1 year later, we found that new HCV infection occurred in $0.74 \%$ and new or repeated HBV infection occurred in $6.5 \%$ of the children, indicating distinct transmission patterns between HBV and HCV. Children of anti-HCVpositive mothers were either anti-HCV-negative or were infected by distinct genotypes of HCV from those infecting their mothers; most married couples in whom both were infected, were infected by HCV of discordant genotypes, indicating negligible importance of sexual or vertical HCV transmission. A casecontrol study comparing 13 anti-HCV-positive and 53 anti-HCV-negative children showed that having received parenteral medication in local clinics was a significant risk for HCV infection. Our data indicate that, unlike the case of HBV, HCV transmission by vertical or sexual route, or through casual contact are extremely inefficient, and our data further suggest that HCV hyperendemicity is unlikely to persist as a result of the more stringent practice of parenteral precautions in nearly all aspects of daily life. J. Med. Virol. 52:370-376, 1997. @ 1997 Wiley-Liss, Inc.

KEY WORDS: HBV; HCV genotype; incidence; parenteral transmission; sexual transmission; vertical transmission

\section{INTRODUCTION}

Hepatitis B virus (HBV) and hepatitis C virus (HCV) are both blood-borne hepatotropic viruses causing chronic persistent infection and significant long term morbidity and mortality [Beasley et al., 1981; Tsai et al., 1994; Simonetti et al, 1992; Sallie and DiBisceglie, 1994]. Despite leaps in improving the safety of blood transfusion with available serologic tests in recent years, high rates of HBV infection continue among new birth cohorts via efficient nonparenteral transmission of the virus in many areas, including Taiwan [Stevens et al., 1975; Tong et al., 1994; Shapiro and Margolis, 1992]. This high transmission rate of infected individuals to their contacts was the main reason that blood screening and sterilising contaminated surgical equipment had a limited impact on reducing hyperendemic HBV levels prior to the introduction of HBV mass immunisation to infants.

In comparison, HCV infection among blood donors or the general population is mostly low (1-2\%) even in areas where HBV infection is endemic [Degos 1994; Bhandari and Wright, 1995; McCarthy et al., 1994; Ochi et al., 1991; Soni et al., 1993; Biltz et al., 1994]. This discrepancy between the high HBV and low HCV infection rates has been mainly attributed to a lack of introduction of HCV to the community. High prevalence of antibody against HCV (anti-HCV) has been sporadically documented in Egypt and several other isolated communities, and parenteral injections via contaminated needles have been ascribed to transmit

Presented at the Tenth International Congress of Virology, J erusalem, Israel, 11-16 August 1996.

Contract grant sponsor: Taiwan National Science Council; Contract grant number: NSC 81-0419-B001-510.

*Correspondence to: Mei-Shang Ho, M.D., Division of E pidemiology and Public Health, Institute of Biomedical Sciences, Academia Sinica, Taipei, Taiwan 11529. E-mail: HOMS@ibms. Sinica.edu.tw

Accepted 7 March 1997 
HCV [Darwish et al., 1992; Abdel-wahab et al., 1994; Bassily et al., 1995; Hayashi et al., 1995; Tawaraya et al., 1995; Ohkoshi et al., 1995]. Since most HCV infections result in a state of chronic infection, accumulation of chronic HCV infections coupled with efficient nonparenteral transmission of HCV could plausibly give rise to persistent hyperendemic HCV infection, resembling that of HBV in Taiwan and other parts of Asia.

In this study, we report on a community where inhabitants had extremely high rates of HBV and HCV infection, yet the two viruses exhibited distinct epidemiologic features which implied differences in the efficiency of viral transmission through vertical and horizontal transmission. Elucidating the relative contribution of various modes of transmission of blood-borne viruses could help to direct our efforts towards appropriate intervention strategies in order to achieve viral hepatitis prevention and control.

\section{SUBJ ECTS AND METHODS Adult Subjects}

The site of this study was an aboriginal village in the mountainous Eastern Taiwan that had a population of 1,853 inhabitants in 465 families in 1993. This community was chosen because its inhabitants had been noted to have high rate $(43 \%)$ of anti-HCV prevalence in a 1991 island-wide survey of aboriginal villages, undertaken because some aboriginal villages were noted to have higher prevalence of anti-HCV [Wu et al., 1992; and records of the National Institute of Preventive Medicine]. In order to avoid collecting data from household members with similar risk exposures, we solicited only one adult of a specified age range from each of 80 households that had been selected by stratified random sampling according to the address of each household. From each of the 80 study subjects, we obtained information on their past medical history, experience in folk medicinal remedies, religious practice, life-long occupational history, sexual contacts, exposure to primate house pets, and general family hygienic profiles, that might all potentially be risk factors for blood-borne viral infection. In addition, members of 51 out of the 80 selected households agreed to partici pate in a serologic survey which focused on mother/child and husband/ wife pairs.

\section{Children}

A serologic survey of HCV was conducted for all children in elementary and middle schools in the village (aged 7-14 years). Most of these children were born prior to the initiation of national HBV immunisation, so that childhood transmission of HBV and HCV within the same population may be compared. In addition, we administered a questionnaire to 13 antiHCV seropositive children and to 53 comparably aged anti-HCV seronegative ( 1 to 4 case/control ratio) control subjects in order to elucidate the potential risk for $\mathrm{HCV}$ infection among children. The questionnaire included medical history, health-seeking habits, experi- ences of folk medicine, and information concerning general sanitary conditions within each household such as exposures to lice, bedbugs, mosquitoes, household pets, sharing of personal items (toothbrush and towels), sharing of beds, number of bathrooms, and total rooms in each household, etc. To further assess the ongoing activities of transmission of HCV among children, we returned to the schools for a follow-up serosurvey 12 months later, and 270 of the original 559 participating children agreed to have a follow-up venopuncture.

\section{HBV and HCV Diagnostic Methods}

HBV surface antigen (HBsAg) and total antibodies against HBV core protein (anti-HBc of IgG and IgM ) and HBsAg (anti-HBs) were detected by using commercially available radioimmunoassay (RIA) kits (Ausriall, Abbott Laboratory, North Chicago, IL). Antibody against HCV (anti-HCV) was detected by using commercially available second-generation enzyme immunoassay (EIA) kits (Abbott Laboratory, North Chicago, IL). The HCV RNA was extracted from serum before being subjected to a reverse transcriptase and polymerase chain reaction (RT-PCR) as described previously [Huang et al., 1993]. HCV was genotyped according to a previously described method [Okamoto et al., 1992]. Specific precautions in conducting RT-PCR procedures to prevent contamination were strictly implemented as described previously [Huang et al., 1993].

\section{Data Analysis}

All collected information was compiled in a computerised format and analysed using Statistical Analysis Software (SAS). Mantel-Haenszel Chi square and test for trend, and Fisher's exact test were used to test for significance.

\section{RESULTS \\ Prevalence and Risk of HCV Infection in Adults}

Overall, $41.3 \%$ (33) of the 80 asymptomatic adults were anti-HCV positive, and $72.7 \%$ (24/33) of the antiHCV seropositive individuals also had in their serum detectable HCV-specific RNA. The age-specific antiHCV positive rates obtained in 1993 were similar to those obtained in 1991, showing high rates among all adults except for those younger than 30 years of age, correlated well with the results obtained in 1991 (Pearson's correlation coefficient $=0.96, \mathrm{P}=0.003$; Table I). Among all the factors known to be risks for HCV infection, i.e., transfusion, tattooing, or acupuncture, none were found to be associated with HCV infection. However, those villagers who had worked and resided away from the village for an extended period of time had a significantly lower HCV infection rates than those who never resided outside of the village (Table II). AntiHCV positive rate was $56.9 \%$ among the 51 villagers who had resided outside of the village as compared to $14.3 \%$ of anti-HCV positive rate among the 21 villagers who never resided away from the village $(P=0.002$, Fisher's exact). Since a majority of young adults under 30 years of age $(62.5 \%)$ had worked and resided outsi de 
TABLE I. Age-Specific Seropositive Rates of Antibody

Against Hepatitis C Virus (Anti-HCV) Among Adult Villagers in Two Separate Surveys

\begin{tabular}{|c|c|c|c|c|}
\hline \multirow{3}{*}{$\frac{\text { Age }}{\text { (Year) }}$} & \multicolumn{4}{|c|}{ Anti-HCV positivity ${ }^{a}$} \\
\hline & \multicolumn{2}{|c|}{$1991(\mathrm{~N}=126)$} & \multicolumn{2}{|c|}{$1993(\mathrm{~N}=80)$} \\
\hline & $\%$ & $(\mathrm{~N})$ & $\%$ & $(\mathrm{~N})$ \\
\hline $\begin{array}{l}<20 \\
20-29 \\
30-39 \\
40-49 \\
50-59 \\
60-69 \\
\geqslant 70\end{array}$ & $\begin{array}{c}0 \\
15.8 \\
42.9 \\
46.7 \\
43.8 \\
73.5 \\
55.6\end{array}$ & $\begin{array}{r}(34) \\
(19) \\
(14) \\
(15) \\
(16) \\
(19) \\
(9)\end{array}$ & $\begin{array}{r}\overline{6} .3 \\
42.9 \\
36.4 \\
50.0 \\
68.9 \\
54.5\end{array}$ & $\begin{array}{l}-\overline{16}) \\
(14) \\
(11) \\
(12) \\
(16) \\
(11)\end{array}$ \\
\hline
\end{tabular}

${ }^{a} \mathrm{High}$ correlation of age-specific anti-HVC positive rates between results of the two surveys (Pearson correlation coefficient $=0.96, \mathrm{P}=$ 0.003 ).

of the village and since the younger age group also had a much lower anti-HCV prevalence (6.3-15.8\%), the potential confounding effect of the younger age group could be reduced by limiting the analysis to villagers of 30 years or older (Table III). The protective effect of being absent from the village remained significant $(P$ $=0.04$, Fisher's exact). The protective effect of being absent from the village was further substantiated by the observation that the duration of residing outside of the village was inversely correlated with a decreasing infection rates ( $P=0.004, \mathrm{M}-\mathrm{H}$ test for trend). Specifically, residing in the village during the 5-year period 1980 through 1984 posed a significant risk becasue $12.5 \%(1 / 8)$ of those who were absent versus $60 \%$ (30/ 50 ) of those who resided in the village during that period was anti-HCV positive ( $P=0.016$, Fisher's Exact). Absence from the village before 1980 showed a similar trend of HCV risk, i.e., $0 \%$ of those who were absent were infected vs. $57.4 \%$ of those who resided in the village were infected by HCV ( $P=0.08$, Fisher's exact), but too few study subjects were suitable for analysis of this period to yield a significant test. For the years after 1985, risk for HCV within this village seemed to have diminished, i.e., $20.0 .7 \%$ infection among those who resided in the village vs. $0 \%$ infection among those who resided away from the village $(P=0.375$, Fisher's exact). Since nearly all villagers were manual labourers or farmers regardless the location of their residence, no specific occupation could be identified to be either a risk for or a protective factor against HCV infection.

\section{The Family Study}

We found no evidence of mother-to-child transmission in the village. Among the 30 children whose mothers were anti-HCV-positive, only three were anti-HCV positive themselves. None of the three children, however, were infected by the same genotype of HCV as that infecting their mothers; two children were infected by type-IV and one by type-I while the mothers were all infected by type-II. In addition, four anti-HCVnegative mothers with anti-HCV-positive children suggested that transmission had occurred via routes other than that of mother-to-child in nature. Although four HCV genotypes were found to circulate within the community, types I (47.1\%) and II (46.2) constituted all but four isolates. While types I and II infected adults with similar frequency, children were infected by types I, II, and IV. Therefore, the distribution of HCV genotypes infecting adults was distinct from that infecting children (chi square with four degrees of freedom, $\mathrm{P}=$ 0.007) (Table IV).

The potential for sexual transmission of HCV between husband and wife was investigated. Among the 28 married couples aged between 31 and 63, there were seven couples who were both infected by HCV, 12 couples among whom only one was infected, and nine couples among whom neither were infected. In only three of the seven couples, the husband and wife were infected by the same genotype of HCV while discordant genotypes were found in the other four couples.

To examine whether both blood-borne viruses HBV and HCV might cocirculate among individuals with similar risks, we examined the 208 household members for the probability of coinfection by both viruses. The acquisition of HCV infection (anti-HCV positive) was probably independent of the acquisition of HBV infection (anti-HBc positivity) because anti-HBc seropositivity among anti-HCV positive individuals was not significantly different from that among the anti-HCV negative individuals ( $P=0.07$ ) (Table V). However, the carrier rate of HBsAg was paradoxically lower (22.2\%) among the anti-HCV positive individuals than that (40.4\%) among the anti-HCV-negative individuals when the 155 anti-HBc positive individuals were analysed (Chi square, $\mathrm{P}<0.05$ ).

\section{HCV and HBV Infection in Children}

A total of 559 school children participated in the serosurvey, 11 tested positive for anti-HCV (1.9\%; Table VI); 10 of the 11 anti-HCV positive children also had in their serum detectable HCV-specific RNA. HBV infection rates were much higher than that of HCV; $69.3 \%$ were positive for anti-HBC, indicating a history of HBV infection, and $29.3 \%$ were chronic HBsAg carriers. A follow-up serosurvey was conducted 12 months after the initial study to include 270 children, representing $49 \%$ of the initial population. Only two $(0.74 \%)$ children showed a positive anti-HCV seroconversion during this 12 month period. However, four children had a negative anti-HCV seroconversion during the same period, indicating a decrease in HCV prevalence among children over the study period. Positive HBsAg seroconversion occurred in four (1.7\%) children, but two children had a negative HBsAg seroconversion. In addition, 12 (4.8\%) children had an uncomplicated HBV infection as evidenced by a positive anti-HBc seroconversion in eight children or a substantial rise of pre-existing antiHBs in four children within the interim. Therefore, transmission of HBV infection, either new or repeated infections, occurred in $16 / 270(6.5 \%, 95 \% \mathrm{Cl}=3.6 \%$, $9.4 \%)$ of the children, that is eight times that of the transmission rate of $\operatorname{HCV}(0.74 \%, 95 \%=-0.28 \%$, 
TABLE II. HVC Infection Rates Among 80 Adult Subjects With or Without Potential Risks

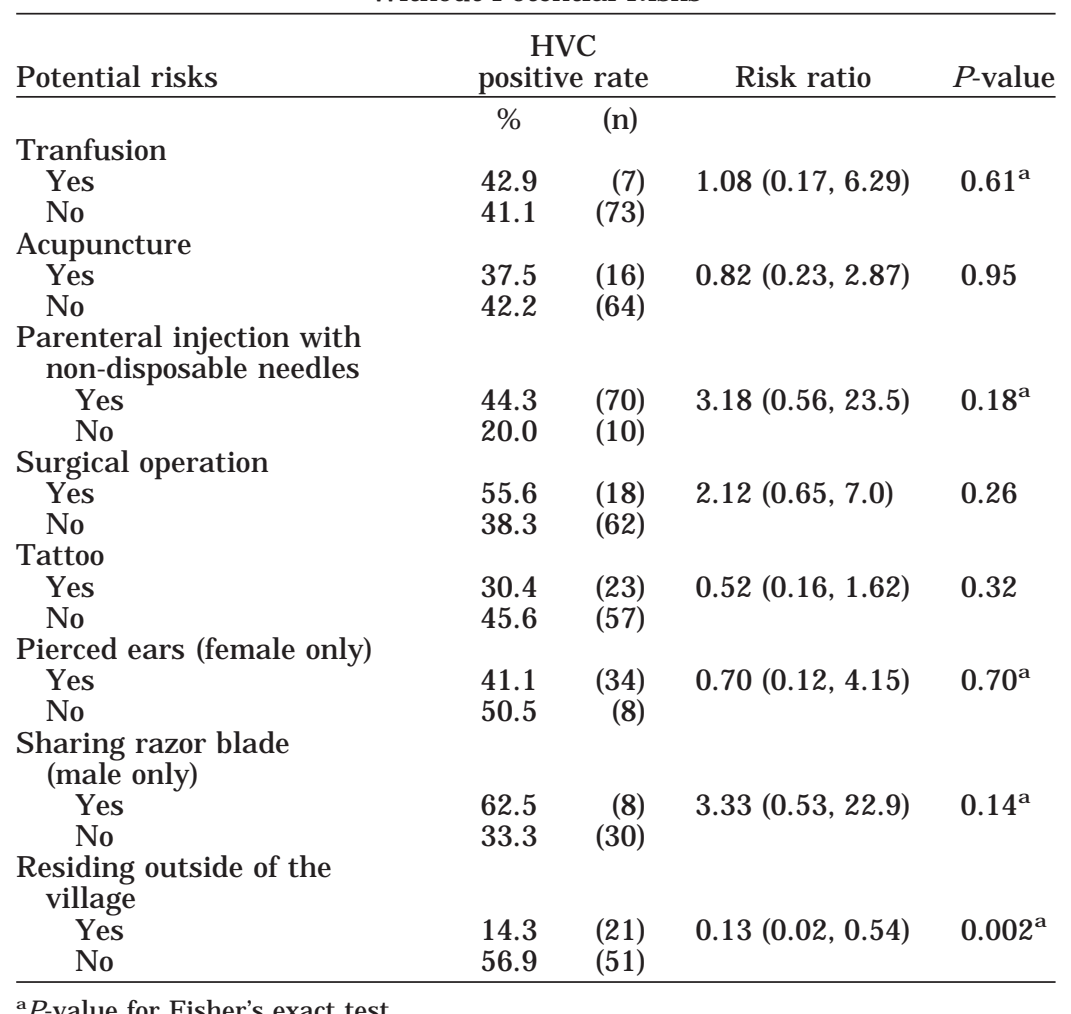

TABLE III. Being Absent From the Village was a Protective Factor Against HCV Infection Among the Villagers Who Were Over 30 Years of Age

\begin{tabular}{|c|c|c|c|c|}
\hline \multirow{2}{*}{$\begin{array}{l}\text { Status of } \\
\text { residence } \\
\end{array}$} & \multicolumn{2}{|c|}{$\begin{array}{l}\text { Anti-HCV } \\
\text { serolog }\end{array}$} & \multirow{2}{*}{$\begin{array}{l}\text { Risk Ratio } \\
(95 \% \text { C.I.) }\end{array}$} & \multirow[b]{2}{*}{ P-value } \\
\hline & Pos. & Neg. & & \\
\hline \multicolumn{5}{|c|}{$\begin{array}{l}\text { Ever absent from } \\
\text { the village }\end{array}$} \\
\hline $\begin{array}{l}\text { Yes } \\
\text { No }\end{array}$ & $\begin{array}{r}3 \\
28\end{array}$ & $\begin{array}{r}9 \\
16\end{array}$ & $0.19(0.03,0.94)$ & $0.0395^{*}$ \\
\hline \multicolumn{5}{|c|}{$\begin{array}{l}\text { Years of absence } \\
\text { from the village } \\
\text { (years) }\end{array}$} \\
\hline $\begin{array}{l}0 \\
1-4 \\
\geqslant 5\end{array}$ & $\begin{array}{r}28 \\
3 \\
0\end{array}$ & $\begin{array}{r}16 \\
2 \\
7\end{array}$ & $\begin{array}{l}1 \\
0.89(0.09,11.7) \\
0.08(0,0.49)\end{array}$ & $0.0036 * *$ \\
\hline
\end{tabular}

*P-value by exact probability.

**P-value by $\mathrm{M}-\mathrm{H}$ test for trend.

$1.76 \%)$ among the same children during 1-year followup period.

The questionnaire survey of the anti-HCV positive and anti-HCV-negative children indicated that none of the children had any of the well-known risk factors for acquiring HCV infection, e.g., blood transfusion, heamodialysis, habitual intravenous drug use, or tattoos. The only risk identified was related to the pattern of how they were cared during childhood $(<5$ years of age). All $13 \mathrm{HCV}$-positive children reported that during early childhood their usual regimen for a bout of minor illness, such as common cold, was to be seen at local
TABLE IV. Distribution of HCV Genotypes Among Anti-HCV-Positive Children and Adults

\begin{tabular}{lrrrrr}
\hline & \multicolumn{4}{c}{ Type of HCV } & HCV RNA \\
\cline { 2 - 5 } Age (years) & I & II & III & IV & Negative \\
\hline Children $<18$ & 6 & 3 & 0 & 3 & 4 \\
Adults $\geqslant 18$ & 19 & 21 & 1 & 0 & 3 \\
\hline P value* & 0.007 & & & &
\end{tabular}

aDual infection by types I and II in one child and four adults; by types II and III in one adult.

*Mantel-Hanszel chi square (d.f. = 3).

clinics or pharmacies where parenteral medication was usually provided. In contrast, none of the 11 children who had never received parenteral medication as a routine regimen for illness was anti-HCV positive (Table VII). The traditional Chinese medical remedies, including acupuncture or bleeding by percutaneously applying a strong vacuum, were not popularly utilised among children in this community.

\section{DISCUSSION}

Blood-borne viruses may be propagated through routes of two major categories: the nonparenteral transmission as from mother to child, between sexual partners, or through other ill-defined forms of close contacts versus direct inoculation of virus percutaneously or intravenously via contaminated vehicles (or fomite) as in the form of blood products, dental or medical instruments, and hypodermic needles. The effi- 
TABLE V. Coinfection of HBV and HCV Among the 208 Household Members

\begin{tabular}{|c|c|c|c|c|c|}
\hline & \multicolumn{4}{|c|}{ Chronic HCV carriers } & \multirow[b]{3}{*}{ P-value* } \\
\hline & \multicolumn{2}{|c|}{ Yes } & \multicolumn{2}{|c|}{ No } & \\
\hline & $\mathrm{n}$ & (\%) & $\mathrm{n}$ & $(\%)$ & \\
\hline $\begin{array}{l}\text { Anti-HBc serology } \\
(n=208) \\
\text { Pos. } \\
\text { Neg. }\end{array}$ & $\begin{array}{r}45 \\
9\end{array}$ & $\begin{array}{l}(83.3) \\
(16.7)\end{array}$ & $\begin{array}{r}109 \\
45\end{array}$ & $\begin{array}{l}(70.8) \\
(29.2)\end{array}$ & 0.07 \\
\hline $\begin{array}{l}\text { Chronic HBsAg carriers } \\
\text { (n = 155) } \\
\text { Yes } \\
\text { No }\end{array}$ & $\begin{array}{l}10 \\
35\end{array}$ & $\begin{array}{l}(22.2) \\
(77.8)\end{array}$ & $\begin{array}{l}44 \\
65\end{array}$ & $\begin{array}{l}(40.4) \\
(59.6)\end{array}$ & 0.03 \\
\hline
\end{tabular}

*Mantel-Haenszel chi square.

ciency of the latter route in transmitting virus is substantial for all blood-borne-viruses, whereas the efficiency of former is variable depending on the type and titer of the virus.

In the case of HBV, early childhood acquisition of HBV via vertical or horizontal non-parenteral transmission is of pivotal importance in rendering lifelong chronic infection in an individual and preserving viral reservoirs within a population [Stevens et al., 1975; Beasley et al., 1982]. In this study, we investigated vertical and horizontal HCV transmission among children in a community with evidence of hyperendemic HCV infection (30-40\%) among adult inhabitants by serologic tests and RNA study. Despite continuous exposure within the household, children were largely uninfected, indicating that vertical and horizontal HCV transmissions are of minute importance-quite different from the case of HBV. That the ongoing horizontal transmission was low for HCV but high for HBV and a lack of clustering of these two viral infections, i.e., a disproportionate number infected by either both viruses or neither, among the household members provided further evidence that these two viruses did not share common sources for their transmission. Based on findings in this and other studies showing that the reproductive rate to the spouse and other household contacts of an HCV-infected individual is much less than one [Biltz-Dorfman et al., 1994; Buchbinder et al., 1994; Ho et al., 1994; Thomas et al., 1995; Nakashima et al., 1995], we conclude that nonparenteral transmission alone is neither capable of escalating the HCV prevalence in a community from a low level to a hyperendemic state nor able to sustain the hyperendemic state of HCV infection within a community.

As to the cause of high HCV infection in isolated communities, following several previous unfruitful searches [Hayashi et al., 1995; Tawaraya et al., 1995; Wu et al., 1992], we ascertained, through investigation of life-long residential histories of villagers, that physical presence in the village in a specified period in the past was prerequisite for risk exposure to HCV infection within the village. It is not clear if the mere absence from the village was protective or if the experience of having resided outside of the village might have altered their life style towards a reduced risk for HCV infection. We have been unable to further discern either conventional known risks or any unique tribal or religious rituals that might involve group activities of percutaneous puncture or communal sharing of body fluid. The epidemiologic data did provide evidence that this risk has been greatly reduced in the past decade. It is worth noting that a clinic in the village was al legedly operated by an unlicensed physician until recent years, and receiving parenteral injections at a public or a private clinic was a common experience among a great majority (87.5\%) of our study subjects, including both children and adults. Differential rates of HCV infection were observed for those with vs. those without parenteral injection for both adults and children. There were too few adults totally devoid of this risk exposure for a meaningful comparison, but children's risk for HCV infection was significantly linked to receiving parenteral injection in local clinic and pharmacy. Disposable syringes and needles gained universal popularity to replace reusable needles in Taiwan only in the last decade [Chen et al., 1995; Wu et al., 1992]. The isolated population and their exposure to insufficiently sterilised reusable hypodermic needles at a limited number of clinics and pharmacies could conceivably resemble needle-sharing among groups of intravenous drug addicts in whom extremely high rates (up to $80 \%$ ) of HVC infection have been documented [Garfein et al., 1996; Galeazzi et al., 1995; Goodrick et al., 1994]. For future control of HCV infection in this community or other similar communities with high prevalence of anti-HCV [Hayashi et al., 1995; Delaporte et al., 1993; Goto et al., 1993], monitoring HCV prevalence among children can best reflect ongoing HCV transmission. In fact, we have systematically surveyed school children in several rural aboriginal villages in Taiwan and found an uniformly low $(<2 \%)$ anti-HCV positive rates (National Institute of Preventive Medicine, unpublished data). In the rare instance of a high anti-HCV positive rate among children [Ngatchu et al., 1992], we suggest a vigorous search for an ongoing parenteral risk, which should be preventable with current technology.

\section{Implication for HCV Control}

The advances in serologic testing of viruses and sterilisation techniques, as well as better enforcement in using disposable needles, will lessen the importance of HCV among general population but will most likely further highlight the certain subgroups with continuing parenteral risk, such as intravenous drug addicts who al ready constitute the largest portion of HCV infections in many devel oped countries [Alter et al., 1990; Conry-Cantilena et al., 1996; MacLindon et al., 1995]. In addition to more innovative education programs, policy modification might become necessary in dealing with blood-borne viruses among drug addicts. In developing countries where serologic screening for HCV is not yet available, instituting screening programs should be the top priority for HCV control. Furthermore, considering the minute importance of nonparenteral transmission of HCV and the reduction of paren- 
TABLE VI. Prevalence and Incidence of HCV and HBV Among Children 7 to 14 Years of Age

\begin{tabular}{|c|c|c|c|c|c|c|c|c|}
\hline \multirow{2}{*}{$\begin{array}{l}\text { Age in } \\
1993 \\
\text { (year) }\end{array}$} & \multicolumn{4}{|c|}{$\begin{array}{c}\text { Prevalence (1993) } \\
(\%)\end{array}$} & \multicolumn{4}{|c|}{$\begin{array}{c}\text { New seroconversion }{ }^{a} \\
(1993-1994) \\
\text { (cases per } 100 \text { person-year) }\end{array}$} \\
\hline & $\mathrm{N}$ & $\begin{array}{c}\mathrm{HCV} \\
\text { antibody }\end{array}$ & $\begin{array}{c}\text { HBV } \\
\text { HBSAg }\end{array}$ & $\begin{array}{l}\text { Anti- } \\
\text { HBC }\end{array}$ & $\mathrm{N}$ & $\begin{array}{c}\mathrm{HCV} \\
\text { antibody }\end{array}$ & HBsAg & $\begin{array}{l}\text { Anti- } \\
\text { HBC }\end{array}$ \\
\hline $\begin{array}{c}7-8 \\
9-10 \\
11-12 \\
13-14\end{array}$ & $\begin{array}{r}80 \\
103 \\
100 \\
276\end{array}$ & $\begin{array}{l}2.5 \\
2.4 \\
3.0 \\
1.5\end{array}$ & $\begin{array}{l}23.8 \\
14.6 \\
44.0 \\
30.4\end{array}$ & $\begin{array}{l}51.3 \\
61.2 \\
80.0 \\
73.9\end{array}$ & $\begin{array}{r}47 \\
62 \\
57 \\
104\end{array}$ & $\begin{array}{l}0 \\
0 \\
0 \\
1.9\end{array}$ & $\begin{array}{l}0 \\
3.2 \\
1.8 \\
1.0\end{array}$ & $\begin{array}{r}10.6 \\
3.2 \\
1.7 \\
4.8\end{array}$ \\
\hline Total & 559 & 1.9 & 29.0 & 69.4 & 270 & 0.74 & 1.5 & 4.8 \\
\hline
\end{tabular}

aSeroconversion rate $=$ Number $\mathrm{HBsAg}$ positives $\div$ total number of children in each age group regardless of their susceptibility.

TABLE VII. HCV Infection in Children was Associated With a History of Receiving Parenteral Injection $(\mathrm{N}=66)$

\begin{tabular}{|c|c|c|c|c|}
\hline \multirow[t]{2}{*}{$\begin{array}{l}\text { Patterns of medical care } \\
\text { received during illness }\end{array}$} & \multicolumn{2}{|c|}{$\begin{array}{c}\mathrm{HCV} \\
\text { positive rate }\end{array}$} & \multirow[t]{2}{*}{$\begin{array}{l}\text { Risk } \\
\text { ratio }\end{array}$} & \multirow[t]{2}{*}{ P-value* } \\
\hline & $\%$ & (n) & & \\
\hline \multicolumn{5}{|l|}{ Parenteral therapy } \\
\hline Yes & 24.1 & $(13 / 54)$ & 8.13 & 0.05 \\
\hline No & 0.0 & $(0 / 12)$ & & \\
\hline \multicolumn{5}{|l|}{ Home-care } \\
\hline Yes & 6.3 & $(1 / 16)$ & 0.21 & 0.11 \\
\hline No & 24.0 & $(12 / 50)$ & & \\
\hline \multirow{2}{*}{\multicolumn{5}{|c|}{$\begin{array}{l}\text { Clinic visit and } \\
\text { parenteral therapy }\end{array}$}} \\
\hline & & & & \\
\hline Yes & 25.0 & $(13 / 52)$ & 9.69 & 0.03 \\
\hline No & 0.0 & (0/14) & & \\
\hline
\end{tabular}

*P-value for fisher's exact test.

teral risk, developing a HCV vaccine for use in the general population becomes a lower priority than the control measures discussed above. For individuals who are already infected by both HBV and HCV, the longterm health consequences warrant monitoring to achieve early detection of hepatocellular carcinoma [Tsai et al, 1994]. The epidemiologic observation of an inverse correlation between HCV infection and HBsAg carrier status in this and other studies [Ko et al, 1992; Liaw et al., 1994], in conjunction with the in vitro corroboration in that cotransfection of HCV core protein and HBV DNA can result in suppression of HBV replication and protein expression [Shih et al., 1993] may prove to be of use in clinical application if further elucidated.

\section{ACKNOWLEDGMENTS}

The work was carried out with the assistance of medical and nursing staff at the Public Health Bureau of Hwalin County and the Field Epidemiologic Training Program (FETP) of the Department of Health, Taiwan. The authors thank Drs. Cyprian Weaver and Kow-Tong Chen for their assistance.

Grant support: Taiwan National Science Council (\#NSC 81-0419-B001-510) and institutional grant of the Academia Sinica (1993-1994) and National Institute of Preventive Medicine (1993-1994).

\section{REFERENCES}

Abdel-wahab M, Zakaria S, Kamel M, Abdel-Khaliq MK, Mabrouk MA, Salama H, Esmat G, Thomas DL, Strickland GT (1994): High seroprevalence of hepatitis $\mathrm{C}$ infection among risk groups in Egypt. American J ournal of Tropical Medicine and Hygiene 51: 563-567.

Alter MJ, Hadler SC, J udson FN, Mares A, Alexander WJ , Hu PY, Miller J K, Moyer LA, Fields HA, Bradley DW, Margolis HS (1990): Risk factors for acute non-A, non-B hepatitis in the United States and association with hepatitis $C$ virus infection. J ournal of the American Medical Association 264:2231-2235.

Bassily S, Hyams K, Fouad R, Samaan M, Hibbs R (1995): A high risk of hepatitis $C$ infection among Egyptian blood donors: The role of parenteral drug abuse. American J ournal of Tropical Medicine and Hygiene 52:503-505.

Beasley RP, Hwang LY, Lin CC, Chien CS (1998): Hepatocellular carcinoma and hepatitis B virus. A prospectivestudy of 22707 men in Taiwan. Lancet II:1129-1133.

Bhandari B, Wright T (1995): Hepatitis C: An overview. Annual Review of Medicine 46:309-317.

Biltz-Dorfman L, Monsalve F, Porto L, Weir J , Arteaga M, Padron G, Leon P, Echevarria J M (1994): Epidemiology of hepatitis C virus in western Venezuela: lack of specific antibody in Indian communities. J ournal of Medical Virology 43:287-290.

Buchbinder SP, Kats MH, Hessol NA, Liu J , O'Malley PM, Alter MJ (1994): Hepatitis C virus infection in sexually active homosexual men. J ournal of I nfection 29:263-269.

Chen TZ, Wu J C, Yen FS, Sheng WY, Hwang SJ , Huo TI, Lee SD (1995): Injection with nondisposable needles as an important route for transmission of acute community-acquired hepatitis $C$ virus infection in Taiwan. J ournal of Medical Virology 46:247-251.

Conry-Cantilena C, VanRaden M, Gibble J, Melpolder J, Shakil OA, Viladomiu L, Cheung L, DiBisceglie A, Hoofnagle J, Shih JW, Kaslow R, Ness P, Alter HJ (1996): Routes of infection, viremia, and liver disease in blood donors found to have hepatitis $C$ virus infection. New England J ournal of Medicine 334:1691-1696.

Darwish NM, Abbas MO, Abdelfattah F M, Darwish MA (1992): Hepatitis $C$ virus infection in blood donors in Egypt. J ournal Egypt Public Health Association 67(3-4):223-236.

Degos F (1994): Epidemiology of hepatitis C virus in Europe. FEMS Microbiology Reviews 14:267-271.

Delaporte E, Thiers V, Dazza MC, Romeo R, Mlika-Cabanne N, Aptel I, Shrijvers D, Brechot C, Larouze B (1993): High level of hepatitis $\mathrm{C}$ endemicity in Gabon, equatorial Africa. Transactions of the Royal Society of Tropical Medicine and Hygiene 87(6):636-637.

Galeazzi B, Tufano A, Barbierato E, Bortolotti F (1995): Hepatitis C virus infection in I talian interavenous drug users: E pidemiological and clinical aspects. Liver 15:209-212.

Garfein RS, Vlahov D, Galai N, Doherty MC, Nelson KE (1996): Viral infections in short term injection drug users: The prevalence of the hepatitis $C$, hepatitis $B$, human immunodefieiency, and human T-lymphotropic viruses. American J ournal of Public Health 86: 655-661.

Goodrick MJ , Gray SF, Rouse AM, Waters Aj, Anderson NA (1994): Hepatitis C (HCV)-positive blood donors in south west England: A case control study. Transfusion Medicine 4:113-119. 
Goto T, Misumi J, Shimaoka A, Aoki K, Yasui T, Kudo M (1993): Seroepidemiological study on hepatitis $C$ virus infection in an endemic area of hepatitis C virus. Kansenshogaku Zasshi 67(7):635641.

Ko YC, Ho MS, Chiang TA, Chang SJ , Chang PY (1992): Tattooing as a risk of hepatitis $C$ virus infection. J ournal of Medical Virology 38(4):288-291.

Kiyosawa K, Tanaka E, Sodeyama T, Y oshizaqa K, Yabu K, F uruta K, I mai H, Nakano Y, Usarda S, Uemura T, Furuta S, Watanabe $Y$ Watanabe J, Fukuda Y, Takayama T, and the South Kiso Hepatitis Study Group (1994): Transmission of hepatitis C in an isolated area in J apan: community-acquired infection. The South Kiso Hepatitis Study Group. Gastroenterology 106(6):1596-1602.

Hayashi J , Kishihara Y, Yamaji K, Yoshimura E, Kawakami Y, Akazawa K, Kashiwagi S (1995): Transmission of hepatitis C virus by health care workers in a rural area of J apan. American J ournal of Gastroenterology 90(5):794-799.

Ho MS, Yang CS, Chen PJ , Mau YC (1994): Intrafamilial transmission of hepatitis C virus. J ournal of Clinical Microbiology 32(11): 2824-2826.

Huang CS, Ho MS, Yang CS, Lee CL, Tan CA (1993): Hepatitis C markers in hemodialysis patients. J ournal of Clinical Microbiology 31(7):1764-1769.

Liaw Y, Tsai S, Chang J, Sheen IS, Chien RN, Lin DY, Chu CM (1994): Displacement of hepatitis B virus by hepatitis C virus as the cause of continuing chronic hepatitis. Gastroenterology 106: 1048-1053.

McCarthy MC, el-Tigani A, Khalid IO, Hyams KC (1994): Hepatitis B and $C$ in J uba, southern Sudan: results of a serosurvey. Transactions of the Royal Society of Tropical Medicine and Hygiene 88(5): 534-536.

MacLindon J P, Paver WK, Babbs C, Yates AD, McMahon RF, Love EM, Craske J , Christopher J , Warnes TW (1995): Hepatitis Crelated chronic liver disease among asymptomatic blood donors in the north west of England. J ournal of I nfection 30:253-259.

Nakashima K, Ikematsu H, Hayashi J, Kihihara Y, Mitsutake A, Kashiwagi S (1995): Intrafamilial transmission of hepatitis C virus among the population of an endemic area of J apan. J ournal of the American Medical Association 274:1459-1461.

Ngatchu T, Stroffolini T, Rapicetta M, Chionne P, Lantum D, Chiaramonte M (1992): Seroprevalence of anti-HCV in an urban child population: A pilot survey in a developing area, Cameroon. J ournal of Tropical Medicine Hygiene 95(1):57-61.

Ochi S, Onji M, Shiraishi K, Ohtu K, AkaoT, Yano Y, Takei N, Matsui H, Ohta Y, Uneda M (1991): Prevalence of hepatitis C virus antibody in an area endemic for hepatitis B virus and human $T$ cell leukaemia virus. J ournal of Gastroenterology Hepatology 6(6): 599-602.

Ohkoshi S, Tawaraya H, Kuwana K, Harada T, Watanake M, higuch S, Kojima H, Kamimura T, Asakura H (1995): A retrospective study of hepatitis $C$ virus carriers in a local endemic town in J a- pan. A possible presence of asymptomatic carrier. Digestive Diseases and Sciences 40(2):465-471.

Okamoto H, Sugiyama Y, Okada S, Kurai K, Akahane Y, Sugai Y, Tanabe T, Sato K, Tsuda F, Miyakawa Y, Mayumi M (1992): Typing hepatitis $C$ virus by polymerase chain reaction with typespecific primers: Application to clinical surveys and tracing infectious sources. J ournal of General Virology 73(Pt 3):673-679.

Sallie R, Di Bisceglie A (1994): Viral hepatitis and hepatocellular carcinoma. Gastroenterology Clinics of North America 23:567579.

Shapiro C, Margolis H (1992): I mpact of hepatitis B virus infection on women and children. Infectious Diseases of Clinical North America 6:75-96.

Shih CM, Lo SJ , Miyamura T, Chen SY, Lee YH (1993): Suppression of hepatitis $B$ virus expression and replication by hepatitis $C$ virus core protein in HuH-7 cells. J ournal of Virology 67(10):5823-5832.

Simonetti R, Camma C, Fiorello F, Politi F, D'Amico G, Pagliaro L (1991): Hepatocellular carcinoma. A world-wide problem and the major risk factors. Digestive Diseases and Sciences 36:962-972.

Simonetti RG, Camma C, Fiorello F, Cottone M, Rapicetta M, Marino L, Fiorentino G, Craxi A, Ciccaglione A, Giuseppetti R, Stroffolini T, Pagliaro L (1992): Hepatitis C virus infection as a risk for hepatocellular carcinoma in patients with cirrhosis. A case-control study. Annals of Internal Medicine 116:97-102.

Soni PN, Tait DR, Kenoyer DG, Fernandes-Costa F, Naicker S, Gopaul W, Simjee AE (1993): Hepatitis C virus antibodies among risk groups in a South African area endemic for hepatitis B virus. J ournal of Medical Virology 40(1):65-68.

Stevens C, Beasley R, Tsui J , Lee W-C (1975): Vertical transmission of hepatitis B antigen in Taiwan. New England J ournal of Medicine 292:771-774.

Tawaraya $\mathrm{H}$, Ohkoshi S, Kuwana K, Watanabe M, Kamimura $\mathrm{T}$, Asakura H (1995): Epidemiologic survey and genetic analysis of endemic hepatitis $C$ virus infection in a J apanese town with a high prevalence of hepatitis B virus carriers. J ournal of Medical Virology 45(4):367-372.

Thomas DL, Zenilman J M, Alter HJ, Shih J N, Galai N, Carella AV, Quinn TC (1995): Sexual transmission of hepatitis C virus among patients attending sexually transmitted diseases clinics in Baltimore-an analysis of 309 sex partnerships. J ournal of Infectious Diseases 171:768-775.

Tong M, Hwang S-J (1994): Hepatitis B rivus infection in Asian Americans. Gastroenterology Clinics of North America 23:523536

Tsai J -F, Chang W-Y, J eng W-Y, Ho M-S, Lin Z-Y, Tsai J -H (1994): Hepatitis $B$ and $C$ virus infeciton as risk factors for liver cirrhosis and cirrhotic hepatocellular carcinoma: A case-control study. Liver 14:98-102.

Wu J -S, Lu C-F, Chou W-H, Chen HY, Lee HF, Wu YC, Lin SY (1992): High prevalence of hepatitis $C$ virus infection in aborigines in Taiwan. J apanese J ournal of Medical Science and Biology 45:165174 